\title{
Environmental influences on distribution of four Sciaenidae species (Actinopterygii, Perciformes) in a tropical bay at Southeastern Brazil
}

\author{
Francisco G. Araújo ${ }^{1,2}$; Francisco J. da C. Guimarães ${ }^{1} \&$ Marcus R. da Costa ${ }^{1}$ \\ ${ }^{1}$ Laboratório de Ecologia de Peixes, Universidade Federal Rural do Rio de Janeiro. Antiga Rodovia Rio-São Paulo km 47, \\ 23851-970 Seropédica, Rio de Janeiro, Brasil. \\ 2 Corresponding author. E-mail: gerson@ufrri.br
}

\begin{abstract}
We sampled fish and measured environmental variables in the Sepetiba Bay, a tropical embayment at Southeastern Brazil. The aim was to assess environmental influences on distribution of four abundant species of Sciaenidae Micropogonias furnieri (Desmarest, 1823), Ctenosciaena gracilicirrhus (Metzelaar, 1919), Cynoscion leiarchus (Cuvier, 1830) and Menticirrhus americanus (Linnaeus, 1758) to test the habitat partition hypothesis. Samples were taken between June 1993 and July 1996, at three bay zones (outer, central and inner). Depth was the most important environmental variable to influence fish distribution, followed by transparency. M. furnieri showed significant negative correlation to depth, transparency and salinity, while $C$. gracilicirrhus showed the opposite situation. The highest densities of $C$. leiarchus occurred in the lowest temperature, while M. americanus did not showed preferences for any of the examined environmental variables. Spatial separation, mainly between $M$. furnieri and $C$. gracilicirrhus, seems to be the strategy developed to coexist in the Sepetiba Bay, with M. furnieri being more adapted to copy with harsh environmental conditions of the inner bay. The other three species, which use mostly the outer bay zone, seem to be restricted to more stable conditions, where influences from oceanic waters are more intense.
\end{abstract}

KEY WORDS. Habitat partition; spatial segregation; strategy.

RESUMO. Influências ambientais na distribuição de quatro espécies de Sciaenidae (Actinopterygii, Perciformes) numa baía tropical do sudeste do Brasil. Foram coletados peixes e medidas as variáveis ambientais na Baía de Sepetiba, uma baía tropical do Sudeste do Brasil. O objetivo foi determinar influências ambientais na distribuição de quatro espécies abundantes de Sciaenidae Micropogonias furnieri (Desmarest, 1823), Ctenosciaena gracilicirrhus (Metzelaar,1919), Cynoscion leiarchus (Cuvier,1830) and Menticirrhus americanus (Linnaeus, 1758) para testar a hipótese de partição do hábitat. Amostragens foram feitas entre Junho de 1993 e Julho de 1996 em três zonas da baía (externa, central e interna). A profundidade foi a mais importante variável ambiental que influenciou a distribuição dos peixes, seguida pela transparência. M. furnieri mostrou uma correlação negativa significante em relação à profundidade, transparência e salinidade, enquanto $C$. gracilicirrhus evidenciou uma situação oposta. As maiores densidades de C. leiarchus ocorreram nas menores temperaturas, enquanto $M$. americanus não parece ter preferências por nenhuma das variáveis ambientais examinadas. A separação espacial, principalmente entre $M$. furnieri e $C$. gracilicirrhus, parece ser uma estratégia desenvolvida para coexistirem na Baía de Sepetiba, com M. furnieri sendo mais adaptada para suportar as condições ambientais mais difíceis da zona interna. As outras três espécies, que utilizam mais a zona externa, parecem ser restritas às mais estáveis condições, onde influências das águas oceânicas são mais intensas. PALAVRAS-CHAVE. Partição de hábitat; segregação espacial; estratégia.

Fishes of the Sciaenidae family is thoroughly distributed in tropical and subtropical oceans (DruZhinin 1974, TREWAVAS 1977, Longhurst \& Pauly 1987, SASAKi 1996) and some species are considered important fisheries resources in several countries (Fischer \& Bianchi 1984, Haimovici et al. 1989). In Sepetiba Bay, a $520 \mathrm{~km}^{2}$ sedimentary embayment at Southeastern Brazil, this group of fishes contributes in great numbers and weight to experimental fishing samples (ARAújo et al. 1998) and to com- mercial fisheries, ranking amongst the most abundant species. The Sepetiba port is a major landing harbour in the State of Rio de Janeiro, contributing up to 147 ton of Sciaenidae yearly, from which $53.1 \%$ of the weight is comprised by Micropogonias furnieri (Desmarest, 1823) (FIPERJ 1998).

The Bay offers shelter for juveniles Sciaenidae, carried into the area, as eggs and larvae, by cold currents from the south (Pessanha et al. 2000, Lima-JúNIOR et al. 2002). In the last 
decade the bay has become increasingly polluted due to municipal and industrial discharges. Unlikely estuaries, bays present lesser changeable environmental conditions and a stable and defined spatial gradient along the axis inner-outer zone, since there is a decreased influence from tides and continental drainage. There is some indication of spatial separation among species in Sepetiba Bay according to different environmental conditions dictated by different bay zones (ArAújo et al. 2002). Among the main water environmental variables to influence fish distribution in bays can be cited salinity, temperature, turbidity and dissolved oxygen (Blaber \& Blaber 1980, WAGNER \& Austin 1999, Whitfield 1999). Additionally, it is believed that the type of substrate will influence on both preys and Sciaenidae distribution, since most species live in a close association with the bottom. Species under environmental pressure try to avoid niche overlapping by optimizing habitat utilization. LIVINGSTON et al. (1976) stated that species-specific different tolerance to changes in salinity and temperature could explain differences in dominant species distribution. Muto et al. (2000) reported Sciaenidae fishes as dominant in the inner shelf at Southeastern Brazil, with Ctenosciaena gracilicirrhus (Metzelaar, 1919), Paralonchurus brasiliensis (Steindachner, 1875) and Cynoscion jamaicensis (Vaillant \& Bocourt, 1883) being the most abundant in the catches, and that temperature was the most important variable to explain fish distribution.

The principle of competitive exclusion states that in a stable community, no two species can be limited by the same factor. Species respond in a different way to factors that vary within communities in space and time, and such variation determines which species can coexist (WhitTAKER \& LEVIN 1975). Different habitat preferences in animals have been interpreted mostly as a result of different adaptive design of the species and/or as result of interspecific competition (STORCH \& FrYNTA 1999). Strategies of resource use must be developed by closed related species to allow coexistence and to avoid competitive exclusion. This principle is not the only response for coexistence mechanisms. Patterns of species occupancy of habitats depend on the densities of the interacting species, the competitive hierarchy among them, the presence of detectable intra-type variation in patch quality, and on their fundamental habitat preferences (RosenzweIg 1981, 1991). Other important evolutionary mechanism to share energetic resources is the temporal succession of species over the annual cycle. CAstello (1986) reported that the longer permanency of some Sciaenidae species in estuarine zones is related to uses and efficient food resource partition, coupled with the capacity of adaptation to environmental conditions.

This work aims to test the hypothesis that there is environmental influence on the distribution of four most abundant Sciaenidae species in the Sepetiba Bay, and that the habitat partition of these closely related species is a mechanism to optimize the use of available resources, with each species responding in different ways to such gradient.

Revista Brasileira de Zoologia 23 (2): 497-508, junho 2006

\section{MATERIAL AND METHODS}

\section{Study area}

Sepetiba Bay (Fig. 1) is situated in the coast of Rio de Janeiro State $\left(22^{\circ} 54^{\prime}-23^{\circ} 04^{\prime} S ; 43^{\circ} 34^{\prime}-44^{\circ} 01^{\prime} \mathrm{W}\right)$ in Southeastern Brazil. It originated by an extensive process of sand deposition, which formed a barrier beach at its southbound end, and has a wide communication with Atlantic Ocean at its west end. The Bay has a mean depth of $8.6 \mathrm{~m}$, a maximum depth of 30 $\mathrm{m}$, and is within a drainage area of $2.700 \mathrm{~km}^{2}$ (FonseCA 1978). Waters are predominantly polyhaline (salinity around 30 ) and annual rainfall is between 1,000 $\mathrm{mm}$ and 2,000 $\mathrm{mm}$ (BARBIERE $\&$ Kronemberger 1994) but this does not influence the Bay salinity much due the existence of only small tributaries. Most of the substrate in the inner Bay is silt and mud. Predominantly northeasterly and southwesterly winds activate thermal currents between the bay and the ocean. Cold and dense oceanic waters, brought by Falkland currents, come into the bay the west side, and mix with warmer freshwater brought into the bay by continental drainage rivers (CoklHo \& CaRvalHo 1973). Tropical climate suffers influence from contrast between plane area and the slope that involve small mountains around the bay. Rainfall peaks occur between December and March and drought, between May and September (BARBIERE \& KRONEMBERGER 1994). In the last decades, the bay has been suffering an increasing degradation process due to industrial outflows and municipal effluents brought into the bay by rivers and drainage channels in the outskirts of Rio de Janeiro city. It is estimated that the bay is receiving industrial outflow of 153,835 $\mathrm{m}^{3} \mathrm{~d}^{-1}$, which corresponds potentially to $3,332 \mathrm{~kg} \mathrm{~d}^{-1}$ DBO5 and 48,694 $\mathrm{kg} \mathrm{d}^{-1}$ suspended solids (Pfeiffer et al. 1985). Recent enhancement of the Sepetiba Bay Port included dredging of the access channel to $20 \mathrm{~m}$ depth, which will enable it to receive ships up to 150,000 ton of capacity.

\section{Sampling programme}

Sampling was conducted during daylight hours, between July 1993 and June 1996, in the three zones (Fig. 1) according to a stratified random design aiming to maximize variation in habitat characteristics, mainly depth, salinity, transparency, temperature and influences of human activities. In each zone, three replicate samples were taken at random, monthly between in 1993 and 1994 and bimonthly in 1995 and 1996. The outer zone had a sandy and gravel bottom and was close to sea limit; the inner zone had a heavy muddy bottom located in a protected area of the Bay; and the middle zone had intermediate bottom characteristics. Bottom trawl tows were against current, of 20-min duration on the bottom, at a towing speed of approximately 1.5 knots and a tow distance of ca. $1500-\mathrm{m}$, thus defining the unit effort. The trawl had an 8-m headline, $11 \mathrm{~m}$ ground rope, $2.5 \mathrm{~cm}$ stretched mesh line on each side, and 1.2$\mathrm{cm}$ mesh cod-end liner. Following each trawl, bottom water was collected by Van Dorn bottle. Temperature was measured with $0.5^{\circ} \mathrm{C}$ precision and salinity with 0.5 precision. Transpar- 


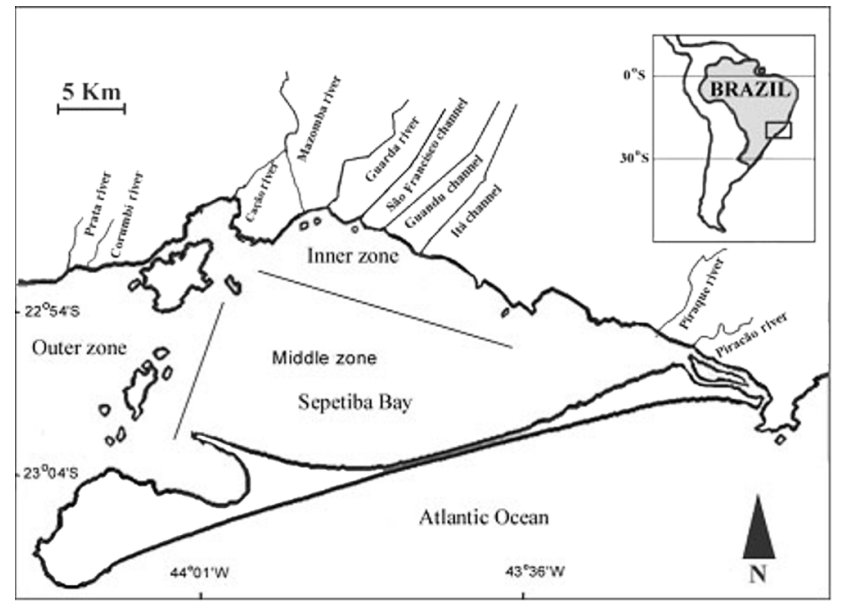

Figure 1. Study area, Sepetiba bay, with indication of the three zones: inner, middle and outer.

ency was recorded using a Secchi disk (in $\mathrm{cm}$ ) and depth was determined with a weighted line marked in $10-\mathrm{cm}$ intervals. One hundred fifty-eight trawling samples were carried in the three bay zones. Fishes were identified, measured to the total length (in millimeters) and weighed (in grams). All fishes were fixed in formalin $10 \%$ and preserved in alcohol $70 \%$.

\section{Data analysis}

Fish and environmental data were $\log (\mathrm{x}+1)$ transformed previously to fulfill homoscedasticity and normality requirements, to validate assumption for parametric analyses applied to the univariate and multivariate tests, to reduce the weighting of abundant species, and to balance the effect of different units of measurement of environmental parameters. The index of relative abundance of fish species was the Capture Per Unit of Effort (CPUE) in terms of number of individuals and biomass. Spatial comparisons in fish and environmental data were accomplished through the zones, and temporal, through seasons. The Kruskal-Wallis test was used to determine whether there were differences among zones and seasons on both fish and environmental data. Man-Whitney test was used to determine differences in mean values for each factor following Kruskal-Wallis. One-way ANOVA were used to compare overall environmental data pooled among zones, years and seasons.

Principal Component Analysis (PCA) applied on environmental data was used to summarise and to describe their relationship and to detect patterns along the bay zones. A Detrended Component Analysis (DCA) on species data was used to explore species distribution patterns; this provides a powerful tool for identifying pattern in the structure of the populations. Canonical correspondence analysis was used to visualize and to describe the relationship between fish species and environmental variables. This ordination method is a powerful multivariate technique that aids in unrevealing how multiple species respond simultaneously to environmental factors, and is designed to extract synthetic environmental gradients from ecological data sets (TER BRAAK 1991). The gradients are the basis for succinctly describing species differential habitat preference via ordination diagrams (Ter BraAK \& Verdondchot 1995). Species and samples sites were marked with points representing their optimum distribution. The explanatory variables are represented by vectors pointing towards the maximum change in the value of the associated variable. Informally, the length is equal to the multiple correlation of the variable with the displayed ordination axes. Additionally, the Spearman rank correlation coefficient was used to determine the significance of relationship between each environmental variable and fish abundance data (ZAR 1984).

\section{RESULTS}

\section{Fish composition}

Five thousand six hundred and ninety-one individuals and $112,154 \mathrm{~g}$ of Sciaenidae fishes comprising in six genera and nine species were recorded in the 158 otter trawls carried out between July 1993 and June 1966 in Sepetiba Bay. Cynoscion was the most diverse genus with five species while the others genera were represented by one species only. The four most abundant species, Micropogonias furnieri, C. gracilicirrhus, Cynoscion leiarchus (Cuvier, 1830) and Menticirrhus americanus (Linnaeus, 1758) amounted to $91.6 \%$ in number and $95.8 \%$ in weight of the total catches, being present in more than $25 \%$ of the samples (Tab. I). Three species, Cynoscion acoupa (Lacépède, 1802), C. jamaicensis and Cynoscion microlepdotus (Cuvier, 1830), were recorded in one occasion only.

\section{Spatial and temporal distribution (Tab. II)}

Micropogonias furnieri: this species was widely distributed throughout the three zones of the Sepetiba Bay, and showed the highest overall abundance in the inner zone. Spatial and temporal relative abundance changed along the three-year studied period. In 1993/1994 and 1994/1995 fishes were more abundant in the inner zones during all seasons, except the summer, when they shift to the middle zone. In 1995/1996, occurred the inverse situation, with the highest abundance in the outer zone during winter/spring, shifting to the middle zone in summer/autumn. Yearly, in 1994/1995 fishes showed the highest abundance and in 1995/1996 the lowest. No seasonal trend can be suggested by the statistical tests for each separated zone, with no significant differences being detected in most comparisons. Exceptions were recorded with comparatively higher values for the middle zone in winter-summer in 1993/1994, and in summer-autumn in 1995/1996, and for the outer zone, during autumn in 1994/1995.

Cynoscion leiarchus: overall the highest abundance was recorded in the outer zone during the winter, but shifts occurred among zones, years and seasons. In 1993/1994 the highest abundance was recorded during winter/spring in the outer zone, decreasing sharply in summer and re-appearing in autumn. In 1994/ 1995 the highest records occurred in summer-autumn in the 
Table I. Number (N), weight (W), frequency of occurrence (Fo) and respective percentages of Sciaenidae species in experimental otter trawl in the Sepetiba Bay, 1993/1996.

\begin{tabular}{|c|c|c|c|c|c|}
\hline Species & $\mathrm{N}$ & $\mathrm{N} \%$ & $\mathrm{~W}$ & W \% & Fo \\
\hline Micropogonias furnieri & 2487 & 43.70 & 62216 & 55.47 & 68.35 \\
\hline Mentichirrus americanus & 397 & 6.98 & 17380 & 15.50 & 58.86 \\
\hline Cynoscion leiarchus & 1921 & 33.76 & 24429 & 21.78 & 37.97 \\
\hline Ctenosciaena gracilicirrhus & 407 & 7.15 & 3384 & 3.02 & 26.58 \\
\hline Isopisthus parvipinnis & 456 & 8.01 & 3788 & 3.38 & 6.33 \\
\hline Paralonchurus brasiliensis & 20 & 0.35 & 723 & 0.64 & 3.16 \\
\hline Cynoscion acoupa & 1 & 0.02 & 25 & 0.02 & 0.63 \\
\hline Cynoscion jamaicensis & 1 & 0.02 & 60 & 0.05 & 0.63 \\
\hline Cynoscion microlepdotus & 1 & 0.02 & 150 & 0.13 & 0.63 \\
\hline Total & 5691 & 100.00 & 112154 & 100.00 & - \\
\hline
\end{tabular}

Table II. Means ((standard error) of CPUE and Kruskal-Walis (KW) comparisons among seasons in the three zones in the Sepetiba Bay, 1993/96. (w) Winter, (s) spring, (su) summer, (a) autumn, (ns) no significance, $\left({ }^{*}\right)$ significant $(p<0.05),\left(^{* *}\right)$ highly significant ( $\left.p<0.01\right)$, (KW) Kruskal-Wallis, (chi-sq) chi-square.

\begin{tabular}{|c|c|c|c|c|c|c|c|c|c|}
\hline \multirow{2}{*}{ Seasons } & \multicolumn{3}{|c|}{ Inner zone } & \multicolumn{3}{|c|}{ Middle Zone } & \multicolumn{3}{|c|}{ Outer Zone } \\
\hline & 1993-94 & 1994-95 & $1995-96$ & 1993-94 & 1994-95 & $1995-96$ & $1993-94$ & 1994-95 & $1995-96$ \\
\hline \multicolumn{10}{|c|}{ Micropogonias furnieri } \\
\hline Winter & $23(12.2)$ & $136(56.2)$ & $2(0.2)$ & $11(6.4)$ & $1(0.3)$ & $2.5(1.1)$ & $6(4.9)$ & $0.3(0.2)$ & $7(5.71)$ \\
\hline Spring & $49(40.9)$ & $5.5(1.7)$ & $36(24.3)$ & $16(10.7)$ & $1(0.7)$ & $3.5(1.7)$ & $32(16.6)$ & $2.3(1.9)$ & $40(32.9)$ \\
\hline Summer & $29(11.5)$ & $21(13.8)$ & $8.5(6.2)$ & $32(0.6)$ & $43(32.2)$ & $14(7.3)$ & $0.2(0.2)$ & $3.6(2.3)$ & $1.3(1)$ \\
\hline Autumn & $10(7.6)$ & $45(28.9)$ & $5.5(3.8)$ & $0.8(0.4)$ & $2.5(0.3)$ & $48(22.2)$ & $0.5(0.1)$ & $9.3(4.7)$ & $0(0)$ \\
\hline KW(chi-sq) & $6.16 \mathrm{~ns}$ & $3.0 \mathrm{~ns}$ & $3.0 \mathrm{~ns}$ & $7.21 *$ & $1.87 \mathrm{~ns}$ & $5.82 *$ & $3.13 \mathrm{~ns}$ & 8.82 * & $1.38 \mathrm{~ns}$ \\
\hline Sig. Differences & - & - & - & w-su > a & - & su-a $>$ w & - & $a>w-s u$ & - \\
\hline \multicolumn{10}{|l|}{ Cynoscion leiarchus } \\
\hline Winter & $1.5(0.7)$ & $10(3.5)$ & $1.5(0.3)$ & $2(0.7)$ & $0(0)$ & $0(0)$ & $50(34.4)$ & $4.6(3.8)$ & $126(103)$ \\
\hline Spring & $0.3(0.3)$ & $0(0)$ & $0.5(0.3)$ & $2.5(2.2)$ & $0(0)$ & $76(50.2)$ & $13(8.2)$ & $0(0)$ & $10(8.1)$ \\
\hline Summer & $0.2(0.1)$ & $3.2(2.8)$ & $4(3.4)$ & $3.8(0.4)$ & $5.2(2.7)$ & $0(0)$ & $0(0)$ & $39(22.3)$ & $0(0)$ \\
\hline Autumn & $4.3(3.4)$ & $0.5(0.3)$ & $0.5(0.3)$ & $1.3(0.7)$ & $0(0)$ & $0(0)$ & $18(12.7)$ & $72(59)$ & $0(0)$ \\
\hline KW(chi-sq) & 4.04 ns & $7.0 \mathrm{~ns}$ & $0.6 \mathrm{~ns}$ & $6.66 \mathrm{~ns}$ & $4.8 \mathrm{~ns}$ & 8.0 * & 11.64 ** & $1.58 \mathrm{~ns}$ & 8.03 * \\
\hline Sig. Differences & - & - & - & - & - & $s>w, s u-a$ & $w-s, a>s u$ & - & $w-s>s u-a$ \\
\hline \multicolumn{10}{|c|}{ Ctenosciena gracilicirrhus } \\
\hline Winter & $0(0)$ & $0(0)$ & $0(0)$ & $1(0.7)$ & $22(15.5)$ & $1.5(1.1)$ & $4.4(2.5)$ & $7.3(3.3)$ & $16(7.3)$ \\
\hline Spring & $0(0)$ & $0(0)$ & $0(0)$ & $1.3(1)$ & $0(0)$ & $0(0)$ & $2(1.1)$ & $0.6(0.5)$ & $0.6(0.5)$ \\
\hline Summer & $0(0)$ & $0(0)$ & $0(0)$ & $1.6(0.2)$ & $0.7(0.6)$ & $0(0)$ & $4(1.4)$ & $1.8(0.8)$ & $2(1.8)$ \\
\hline Autumn & $0(0)$ & $0(0)$ & $0(0)$ & $0.2(0.1)$ & $13(9.5)$ & $0(0)$ & $7.1(3.2)$ & $0(0)$ & $0(0)$ \\
\hline KW(chi-sq) & $0.0 \mathrm{~ns}$ & $0.0 \mathrm{~ns}$ & $0.0 \mathrm{~ns}$ & $1.83 \mathrm{~ns}$ & $2.0 \mathrm{~ns}$ & 4.8 * & $1.15 \mathrm{~ns}$ & $6.16 \mathrm{~ns}$ & $3.04 \mathrm{~ns}$ \\
\hline Sig. Differences & - & - & - & - & - & $w>s-a$ & - & - & - \\
\hline \multicolumn{10}{|c|}{ Mentichirrus americanus } \\
\hline Winter & $1.7(1.2)$ & $7(0.7)$ & $1(0.7)$ & $2(0.7)$ & $6(3.5)$ & $3.5(2.4)$ & $2.4(1.1)$ & $2.3(1.2)$ & $3.3(1.4)$ \\
\hline Spring & $0.8(0.6)$ & $12(5.3)$ & $0.5(0.3)$ & $1.8(0.9)$ & $2(1.4)$ & $2.5(1.7)$ & $1.1(0.4)$ & $0.3(0.3)$ & $4.7(3)$ \\
\hline Summer & $2(0.9)$ & $0.7(0.4)$ & $0.5(0.4)$ & $4(0.2)$ & $3.5(1.6)$ & $1.7(1.2)$ & $1.3(0.4)$ & $12(8.1)$ & $1.5(0.9)$ \\
\hline Autumn & $4(2.4)$ & $1(0.1)$ & $0(0)$ & $2.2(1.3)$ & $2.5(1.1)$ & $1(0.7)$ & $1.1(0.4)$ & $2.7(1.8)$ & $0.3(0.3)$ \\
\hline KW(chi-sq) & $3.19 \mathrm{~ns}$ & $6.0 *$ & $1.33 \mathrm{~ns}$ & $3.38 \mathrm{~ns}$ & $2.0 \mathrm{~ns}$ & $0.0 \mathrm{~ns}$ & $0.65 \mathrm{~ns}$ & $1.58 \mathrm{~ns}$ & $2.0 \mathrm{~ns}$ \\
\hline Sig. Differences & - & $\mathrm{w}, \mathrm{s}>\mathrm{su}, \mathrm{a}$ & - & - & - & - & - & - & - \\
\hline
\end{tabular}


outer zone. In 1995/1996 this species peaks in the winter in the outer zone, moving to the central zone in spring, and then disappearing from the catches in summer/autumn. Significant differences in abundance among seasons for each examined year were detected in three occasions; the highest abundance was recorded in spring in the central zone in 1995/1996, and in winter-spring and autumn in 1993/1994 and 1995/1996, respectively.

Ctenosciaena gracilicirrhus: this was the only abundant Sciaenidae species that was not recorded in the inner zone during the studied period. Overall its highest abundance occurs during the winter, mainly in the outer zone. In 1993/1994 the highest abundance occurred during winter and autumn in the outer zone; in 1994/1995 peaks occurred in winter and autumn in the middle zone, and in winter in the outer zone; and in $1995 / 1996$ in winter in the outer zone.

Menticirrhus americanus: this species, like M. furnieri seems to be distributed all over the bay, with shifts in abundance occurring along the studied period. In 1993/1994 it is likely to be a movement toward the inner part of bay, with peak in abundance in spring in the outer zone, summer in the central, and autumn in the inner zone. The reverse situation seems to occur in 1994/1995, with the highest abundance being recorded in winter/spring in the inner zone, winter in the middle and summer in the outer zone. In 1995/1996, the highest abundance of this species seems to be limited to winter/spring in the outer and central zone. The only significant difference in abundance was recorded for inner zone with the highest records occurring in winter/spring in 1994/1995.

Overall, two patterns of species distribution were detected by DCA, suggesting the spatial segregation of species. The first two axes explained $69.3 \%$ of the total variance (Tab. III). Only axis I explained $50 \%$ of total variance and presented C. gracilicirrhus strongly associated to samples in the outer zone on the right side, while $M$. furnieri was strongly associated to inner zone, on the left side (Fig. 2). The samples group formed by C. gracilicirrhus, C. leiarchus, M. americanus was more associated to the middle and the outer bay zones, on the right side of the diagram, and the samples group associated to the highest abundance of M. furnieri was shown on the left side (Fig. 2). Cynoscion leiarchus and $M$. americanus were more associate to axis II, presenting an opposite pattern of abundance, with the former peaking in outer and middle zones and the latter distributing all over the bay zones (Fig. 2).

Table III. Summary of DCA on abundance of Sciaenidae species for each axis in the Sepetiba, 1993/1996.

\begin{tabular}{lrrrr}
\hline & \multicolumn{4}{c}{ Axes } \\
\cline { 2 - 5 } & 1 & 2 & 3 & 4 \\
\hline Eigenvalues & 0.473 & 0.182 & 0.087 & 0 \\
Lengths of gradient & 2.652 & 2.437 & 2.708 & 0 \\
Percent of cumulative & 50.000 & 69.300 & 78.400 & 0 \\
variance on species data & & & & 0.945 \\
Sum of the eigenvalues & & & & \\
\hline
\end{tabular}

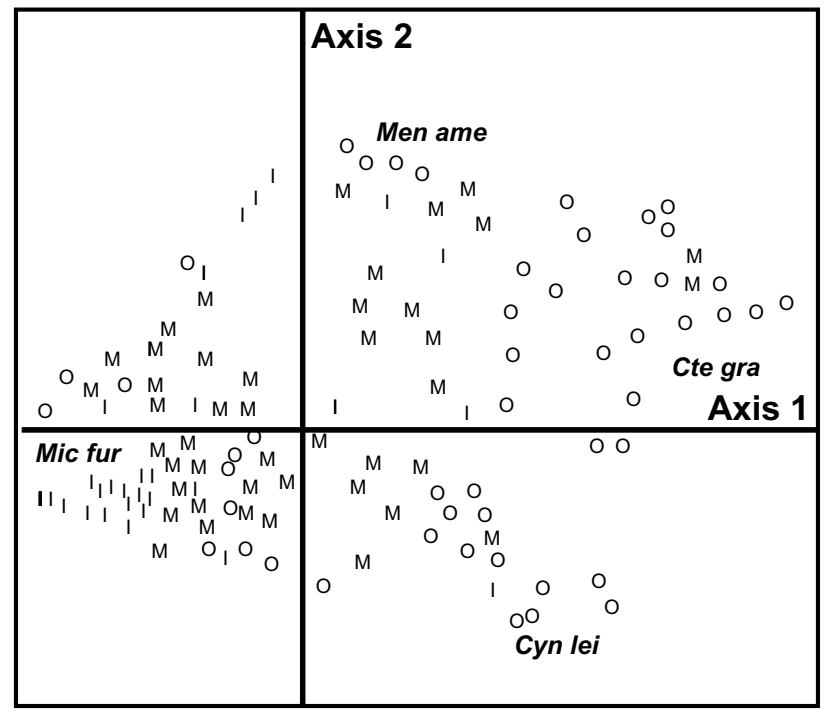

Figure 2. Ordination diagram of the two first axes from DCA on the four Sciaenidae species coded by samples zones in the Sepetiba Bay, 1993/1996. Zones: (I) inner, (M) middle, (O) outer. Species code: (Mic fur) Micropogonias furnieri, (Cte gra) Ctenosciaena gracilicirrhus, (Cyn lei) Cynoscion leiarchus, (Men ame) Menticirrhus americanus.

\section{Environmental variables influences on fish abundance}

Temperature: means ranged from $21.4^{\circ} \mathrm{C}$ in the middle zone during winter $1993 / 1994$, to $27.4^{\circ} \mathrm{C}$ in the inner zone during summer 1994/1995 (Tabs IV and V). There is a clear and consistent seasonal variation in temperature throughout the three zones during the three-year period. The highest values occur in summer, followed by autumn, and the lowest values in winter-spring. A slight non-significant gradient between the three zones was detected, with the highest values in the inner zone and lowest in the outer zone. The 1994/1995 period shows the highest temperature compared to 1993/1994 and 1995/ 1996, mainly in winter-spring-summer, with these differences being highly significant $(\mathrm{p}<0.01)$.

Salinity: the Sepetiba bay is a stable eurihaline environment with few changes in bottom salinity over the zones, years and seasons (Tabs IV and V). Salinity ranged from 23.0 in the inner zone in 1994/1995 to 34.1 in the outer zone during spring $1995 / 1996$. No clear seasonal variation was detected but there is a trend for the highest values occur in spring and the lowest in summer in the middle and outer zone in 1994/1996. A spatial gradient was also detected with lowest values in the inner zone and the highest in the outer zone. A slightly increase in salinity was detected in the three year period, with lowest overall averages in 1993/1994 and the highest in 1995/1996.

Transparency: there is a clear increased transparency gradient from the inner to the outer zone during all seasons throughout the whole studied period (Tabs IV and V). The lowest mean value $(0.9 \mathrm{~m})$ was recorded in the inner zone in spring

Revista Brasileira de Zoologia 23 (2): 497-508, junho 2006 
Table IV. Means (( SE) of environmental variables and Kruskal-Wallis comparisons among seasons in the three zones in the Sepetiba Bay, 1993/96. (w) Winter, (s) spring, (su) summer, (a) autumn, (ns) no significance, $\left({ }^{*}\right)$ significant $(\mathrm{p}<0.05),\left({ }^{* *}\right)$ highly significant $(\mathrm{p}<0.01)$, (KW) Kruskal-Wallis, (chi-sq) Chi-square.

\begin{tabular}{|c|c|c|c|c|c|c|c|c|c|}
\hline \multirow{2}{*}{ Seasons } & \multicolumn{3}{|c|}{ Inner zone } & \multicolumn{3}{|c|}{ Middle zone } & \multicolumn{3}{|c|}{ Outer zone } \\
\hline & 1993-94 & $1994-95$ & $1995-96$ & 1993-94 & 1994-95 & $1995-96$ & 1993-94 & 1994-95 & $1995-96$ \\
\hline \multicolumn{10}{|l|}{ Temperature } \\
\hline Winter & $22.3(0.6)$ & $23.7(1.0)$ & $22.5(0.2)$ & $21.4(0)$ & $24.1(0.9)$ & $22.3(0.4)$ & $21.9(0.6)$ & $23.3(0.4)$ & $22.5(0.4)$ \\
\hline Spring & $24.3(1.9)$ & $26.9(1.5)$ & $22.0(0)$ & $23.8(0.8)$ & $26.5(0.7)$ & $22.5(0.7)$ & 23.1(1.1) & $24.6(0.5)$ & $22.3(0.5)$ \\
\hline Summer & $26.8(1.7)$ & $27.4(1.8)$ & $26.8(1.8)$ & $25.4(1.4)$ & $26.9(1.3)$ & $25.0(0.9)$ & $24,3(2.2)$ & $26.4(1.2)$ & $25.4(1.5)$ \\
\hline Autumn & $26.2(1.4)$ & $24.9(0.1)$ & $24.6(0.3)$ & $25.5(1.8)$ & $24.5(0.7)$ & $23.7(0)$ & $24.6(1.2)$ & $24.6(0.5)$ & $23.6(0.1)$ \\
\hline KW(chi-sq) & $7.54^{\star *}$ & Ns & $8.01^{* *}$ & $5.64^{\star *}$ & ns & $8.73^{* *}$ & $4.07^{\star *}$ & $7.93^{* *}$ & $7.79^{* *}$ \\
\hline Sig. Differences & su-a $>$ s $>$ w & - & $\mathrm{su}>\mathrm{a}>\mathrm{w}, \mathrm{s}$ & su. $a>s>w$ & - & $\mathrm{su}>\mathrm{a}>\mathrm{w}, \mathrm{s}$ & su $>a>w$ & $\mathrm{su}>\mathrm{a}, \mathrm{s}>\mathrm{w}$ & $\mathrm{su}>\mathrm{a}>\mathrm{w}, \mathrm{s}$ \\
\hline \multicolumn{10}{|l|}{ Salinity } \\
\hline Winter & 29.7(1.7) & $30.0(2.8)$ & $31.0(1.4)$ & $30.5(0.7)$ & $34.0(0)$ & $33.0(1.4)$ & $32.2(0.4)$ & $34.0(0)$ & $33.6(1.1)$ \\
\hline Spring & $29.1(1.3)$ & $23.0(9.8)$ & $30.0(0)$ & $30.1(1.3)$ & $30.0(0)$ & $33.5(0.7)$ & $30.7(1.0)$ & $32.0(0)$ & $34.1(0)$ \\
\hline Summer & $29.6(2.0)$ & $30.0(0.8)$ & $28.2(2.6)$ & $31.6(1.6)$ & $30.0(1.6)$ & $30.5(1.0)$ & $31.8(2.1)$ & $30.4(1.1)$ & $31.1(0.9)$ \\
\hline Autumn & $29.5(2.1)$ & $31.0(1.4)$ & $29.5(0.7)$ & $30.8(1.3)$ & $30.0(0)$ & $34.0(0)$ & $31.5(0.5)$ & $32.3(0.5)$ & $34.0(0)$ \\
\hline KW(chi-sq) & ns & ns & ns & ns & $6.40^{\star}$ & $8.21^{* *}$ & ns & $14.23^{* *}$ & $13.15^{\star *}$ \\
\hline Sig. Differences & - & - & - & - & $w>s-a$ & $w-s, a,>s u$ & - & $w>s-a$ & $w-s, a)>s u$ \\
\hline \multicolumn{10}{|l|}{ Transparency } \\
\hline Winter & $1.1(0.4)$ & $2.2(1.7)$ & $1.5(0.7)$ & $1.7(0.6)$ & $3.0(0)$ & $2.5(0.7)$ & $2.7(0.6)$ & $2.5(0.5)$ & $3.1(0.7)$ \\
\hline Spring & $1.0(0.3)$ & $2.5(0.7)$ & $0.9(0.1)$ & $2.8(0.6)$ & $4.2(0.3)$ & $2.0(0)$ & $3.4(0.5)$ & $4.2(0.9)$ & $2.2(0.4)$ \\
\hline Summer & $2.1(0.6)$ & $1.4(0.2)$ & $1.0(0.8)$ & $3.8(0.6)$ & $2.6(1.0)$ & $1.9(1.3)$ & $3.7(0.6)$ & $2.2(0.5)$ & $4.1(1.1)$ \\
\hline Autumn & $2.0(0.8)$ & $2.5(0)$ & $2.2(0.3)$ & $3.2(1.1)$ & $2.3(0.4)$ & $3.5(0.7)$ & $5.4(2.9)$ & $2.5(0.5)$ & $4.8(0.2)$ \\
\hline KW(chi-sq) & $4.03^{*}$ & ns & ns & $3.54^{*}$ & ns & $\mathrm{Nn}$ & $3.48^{*}$ & $6.49^{* *}$ & $5.23^{* *}$ \\
\hline Sig. Differences & su-a > w.s & - & - & su-a $>$ w & - & - & $\mathrm{a}>\mathrm{su}, \mathrm{w}-\mathrm{s}$ & $s>w, s u-a$ & su-au $>$ w-s \\
\hline \multicolumn{10}{|l|}{ Depth } \\
\hline Winter & $3.6(0.4)$ & $4.0(0)$ & $4.7(0.3)$ & $7.6(1.9)$ & $10.5(0.7)$ & $8.5(4.9)$ & $14.1(9.1)$ & $10.3(1.5)$ & $10.6(3.7)$ \\
\hline Spring & $4.0(1.8)$ & $3.2(1.1)$ & $2.8(0.9)$ & $8.6(0.6)$ & $8.5(2.8)$ & $10.0(4.2)$ & $8.8(2.1)$ & $11.0(4.0)$ & $10.1(4.0)$ \\
\hline Summer & $4.2(1.1)$ & $4.5(1.7)$ & $3.2(1.8)$ & $8.6(2.2)$ & $8.7(2.6)$ & $9.0(2.5)$ & $11.5(1.5)$ & $9.3(3.4)$ & $10.6(3.7)$ \\
\hline Autumn & $4.9(2.6)$ & $5.0(2.1)$ & $3.2(0.3)$ & $8.8(1.2)$ & $6.0(0)$ & $9.5(2.1)$ & $12.0(3.6)$ & $9.5(5.0)$ & $12.0(2.0)$ \\
\hline KW(chi-sq) & ns & ns & Ns & Ns & Ns & Ns & ns & ns & ns \\
\hline Sig. Differences & - & - & - & - & - & - & - & - & - \\
\hline
\end{tabular}

Table V. Overall averages and standard errors (in brackets) for pooled environmental variables and F-values from ANOVA for significant differences among zones, years and seasons in Sepetiba Bay, 1993/1996. Seasons: (w) winter, (s) spring, (su) summer, and (a) autumn. ${ }^{* *} \mathrm{p}<0.01$, (ns) non-significant.

\begin{tabular}{|c|c|c|c|c|c|c|}
\hline Environmental Variables & Winter & Spring & Summer & Autumn & $\mathrm{F}$ & Significant Differences \\
\hline Temperature & $22.2(0.2)$ & $23.8(0.3)$ & $25.9(0.3)$ & $24.9(0.2)$ & $85.04 * *$ & $s u>a>s>w$ \\
\hline \multirow[t]{2}{*}{ Salinity } & $31.97(0.29)$ & $30.4(0.5)$ & $30.55(0.27)$ & $31.24(0.31)$ & 14.76 ** & $w>$ su e $w>s$ \\
\hline & $93 / 94(1)$ & $94 / 95(2)$ & $95 / 96(3)$ & & $\mathrm{F}$ & Sig. Difference \\
\hline Temperature & $24.16(0.23)$ & $24.92(0.32)$ & $23.54(0.31)$ & - & $11.05^{\star *}$ & $2>1 ; 2>3$ \\
\hline \multirow[t]{2}{*}{ Salinity } & $30.60(0.19)$ & $31.04(0.46)$ & $31.95(0.34)$ & - & $12.92^{\star *}$ & $3>1$ \\
\hline & Inner zone (in) & Middle zone (mi) & Outer zone (ou) & & $\mathrm{F}$ & Sig. Difference \\
\hline Salinity & $29.45(0.40)$ & $31.30(0.25)$ & $32.06(0.19)$ & - & $37.71^{* *}$ & ou $>\mathrm{mi}>$ in \\
\hline Transparency & $1.67(0.11)$ & $2.90(0.14)$ & $3.57(0.18)$ & - & $62.09 * *$ & ou $>\mathrm{mi}>$ in \\
\hline Depth & $4.05(0.22)$ & $8.75(0.29)$ & $10.87(0.51)$ & - & $90.49 * *$ & ou $>\mathrm{mi}>$ in \\
\hline
\end{tabular}


1995/1996 and the highest (4.8 m) in autumn 1995/1996. Although no seasonal variation could be seen, a slight trend of higher values occurs in summer-autumn, and the lowest in winter-spring.

Depth: there is a clear increasing in depth from the inner to the outer zone (Tabs IV and V). Overall averages ranged from $2.8 \mathrm{~m}$ in spring 1995/1996 in the inner zone to $14.1 \mathrm{~m}$ in winter 1993/1994 in the outer zone. No clear trend of depth variation was found among years and seasons.

The two main axes from PCA on the four environmental variables (temperature, salinity, transparency and depth) showed eigenvalues higher than 1.0 and has explained $75.52 \%$ of the total variance (Tab. VI). Axis I presented the highest contribution for the depth, salinity and transparency, explaining $48.36 \%$ of the total variance, indicating spatial variation over the environmental gradient. Axis II presented highest contribution to temperature, explaining $27.16 \%$ of the total variance (Fig. 3), indicating seasonal variation. The ordination diagram shows a clear spatial separation of the bay zones according to environmental variables along the axis I, with the outer sample zones on the left side, and the inner samples zones on the right side (Fig. 3). The outer bay zones showed higher values for depth, salinity and transparency, while the inner zone presented the opposite situation for these environmental parameters (Fig. 3).

Table VI. Summary of PCA loads on environmental variables in the Sepetiba Bay, 1993/1996.

\begin{tabular}{lrrrc}
\hline \multirow{2}{*}{ Environmental variables } & \multicolumn{4}{c}{ Axes } \\
\cline { 2 - 5 } & \multicolumn{1}{c}{1} & \multicolumn{1}{c}{2} & \multicolumn{1}{c}{3} & \multicolumn{1}{c}{4} \\
\hline Temperature & 0.349 & 0.751 & -0.053 & 0.558 \\
Salinity & -0.576 & -0.233 & -0.466 & 0.630 \\
Transparency & -0.465 & 0.577 & -0.421 & -0.524 \\
Depth & -0.574 & 0.224 & 0.777 & 0.132 \\
Eigenvalues & 1.934 & 1.087 & 0.498 & 0.481 \\
Explained variance & 48.360 & 27.160 & 12.460 & 12.020 \\
Broken-stick Eigenvalues & 2.080 & 1.080 & 0.580 & 0.250 \\
\hline
\end{tabular}

The non-parametric Spearman coefficient showed that abundance of $M$. furnieri were negatively correlated $(p<0.01)$ to salinity, transparency and depth (Tab. VII). The opposite situation was shown for $C$. gracilicirrhus, which was positively correlated $(\mathrm{p}<0.01)$ to these environmental variables. C. leiarchus was negatively correlated to temperature $(\mathrm{p}<0.05)$ and $M$. americanus did not present any correlation to the examined environmental variables.

Canonical correspondence analysis (CCA) showed that depth and transparency were the most important environmental variables to contribute to abundance of the fish species in the Sepetiba Bay. Correlation between species-environmental variables was more significant for the first (0.59) and second

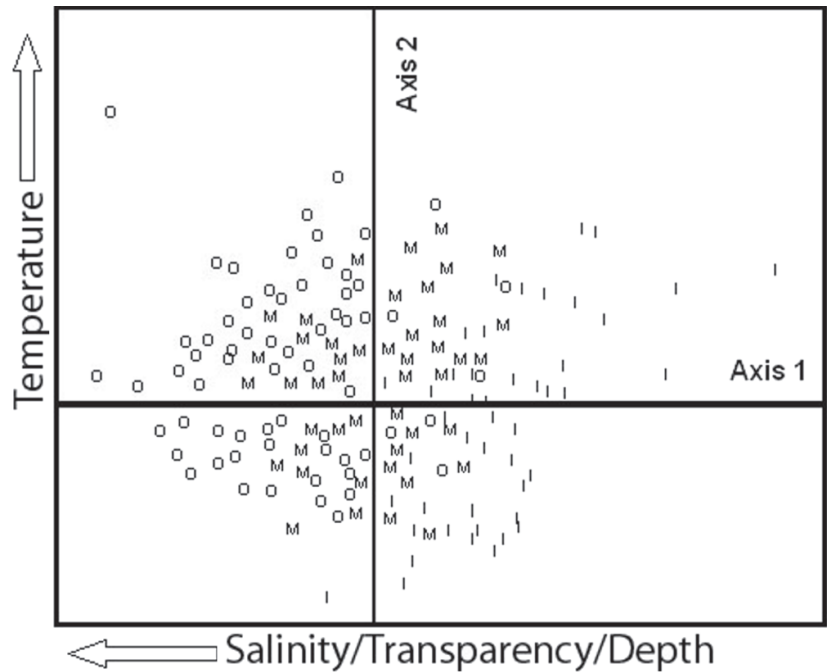

Figure 3. Ordination diagram from PCA on environmental variables in the Sepetiba Bay, 1993/96. Samples coded by zones: (I) inner, $(\mathrm{M})$ middle, $(\mathrm{O})$ outer.

Table VII. Spearman rank correlation coefficient between the four Sciaenidae species and environmental variables in the Sepetiba Bay, 1993/1996.

\begin{tabular}{lclll}
\hline \multicolumn{1}{c}{ Species } & Temperature & Salinity & Transparency & Depth \\
\hline M. furnieri & 0.056 & $-0.301^{* *}$ & $-0.361^{* *}$ & $-0.459^{* *}$ \\
M. americanus & -0.003 & 0.122 & 0.006 & 0.105 \\
C. leiarchus & $-0.183^{*}$ & 0.057 & -0.093 & -0.024 \\
C. gracilicirrhus & -0.148 & $0.316^{* *}$ & $0.273^{* *}$ & $0.401^{* *}$ \\
\hline
\end{tabular}

(0.16) axes, and smaller for the third (0.09) and fourth (0.0) axes (Tab. VIII).

The triplot of sample sites, species and environmental variables on the two main axes as determined by the CCA was shown in figure 4 , and amounted to $98.9 \%$ of the explained variance. Axes 1 separated the zones along the spatial gradient, with the inner zone located on the left part of the diagram and the outer zone on the right side. C. leiarchus was associated to higher depth values, while $M$. americanus, closer the origin, seems not to be influenced by any of these environmental variables. C. gracilicirrhus was associated to highest depth and transparency from the outer and middle zones. M. furnieri, on the other hand, was associated to the lowest depth and salinity in the middle and inner zones.

\section{DISCUSSION}

A marked spatial segregation in distribution of Sciaenidae species in the Sepetiba Bay was observed in this study. The top abundant $M$. furnieri occupies and is the dominant species in the inner zone, M. americanus shifts in occurrence all over the

Revista Brasileira de Zoologia 23 (2): 497-508, junho 2006 
Table VIII. Summary of canonical correspondence analyses on environmental and biotic data at Sepetiba Bay, 1993/1996.

\begin{tabular}{lrrrr}
\hline \multicolumn{1}{c}{ Correlation with } & \multicolumn{5}{c}{ Axes } \\
\cline { 2 - 5 } environmental variables & 1 & 2 & 3 & 4 \\
\hline Temperature & -0.24 & 0.63 & -0.58 & 0 \\
Salinity & 0.62 & -0.41 & 0.32 & 0 \\
Transparency & 0.58 & 0.68 & 0.43 & 0 \\
$\begin{array}{l}\text { Depth } \\
\text { Summary of ordination } \\
\quad \text { axes }\end{array}$ & 0.93 & -0.07 & -0.31 & 0 \\
$\begin{array}{l}\text { Eigenvalues } \\
\text { Environmental-species } \\
\quad \text { correlation }\end{array}$ & 0.165 & 0.007 & 0.002 & 0.342 \\
$\begin{array}{l}\text { Percent of cumulative } \\
\text { variance of species data }\end{array}$ & 17.40 & 18.10 & 18.30 & 0 \\
$\begin{array}{l}\text { Species-environment } \\
\text { correlation }\end{array}$ & 95.00 & 98.80 & 100.00 & 0 \\
\hline $\begin{array}{l}\text { Sum of the eigenvalues } \\
\text { Sum of constrained } \\
\text { canonical eigenvalues }\end{array}$ & & & 0.095 & 0 \\
\hline
\end{tabular}

bay, being common in the central zone, while C. gracilicirrhus and C. leiarchus are common only in the outer zone. According to HARRIs et al. (2001) the main forces structuring the fish assemblages in near shore and bay zones are the interactive effects of the physical environment and differing responses of the various species to physico-chemical conditions. This study determined three slightly different zones along the Sepetiba Bay and different use of such zone by the most abundant Sciaenidae species. According to uni and multivariate analyses, depth and transparency were the main variables to influence fish distribution, determining habitat partition. C. gracilicirrhus and C. leiarchus, occurred mainly in areas with more marine influences, where transparency and depth is high, while $M$. furnieri occurred in warmer, less saline, less transparent and shallow waters. M. americanus show wider distribution, suggesting no preference for any of the examined environmental variables. The first axis of PCA and canonical correspondence analysis were more correlated with depth, transparency and salinity. Temperature was better correlated with the second axis of both analyses, demonstrating a lesser influence on fish abundance.

Depth was the main environmental variable to be associated to the first axis of multivariate analyses, being negatively correlated to abundance of $M$. furnieri, indicating that this species has preference for shallower zones. On the other hand, the positive correlation between depth and C. gracilicirrhus suggests that this species is more abundant in the deepest bay areas. The other two species did not present significant correlation with this variable and were distributed all over the bay but concentrated in the deeper zones (middle and outer zones). Depth may have been significant because it acted in concert with other factors such as sediment. Fargo \& TYler (1991) found four species

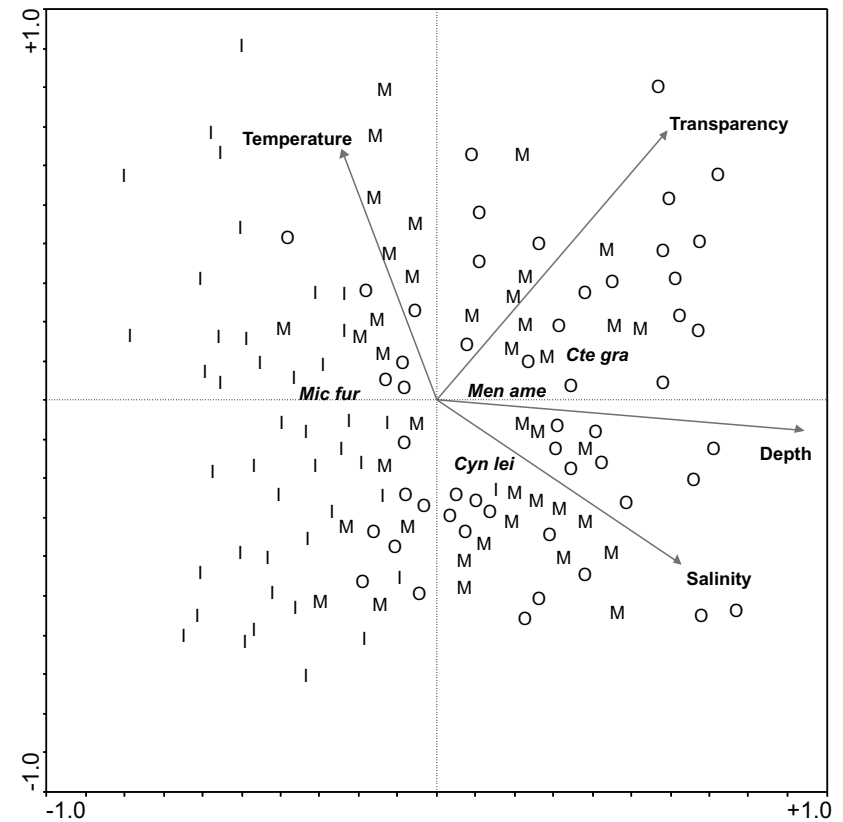

Figure 4. Ordination diagram from Canonical Correspondence Analysis on fish abundance and environmental variables. Zones: (I) inner, (M) middle, (O) outer. Species code: (Mic fur) Micropogonias furnieri, (Cte gra) Ctenosciaena gracilicirrhus, (Cyn lei) Cynoscion leiarchus, (Men ame) Menticirrhus americanus.

assemblages separated by depth and sediment, and the species assemblages and sediment types did not coincide exactly. Caution is necessary because sometimes they vary independently, specially when interpreting distribution of demersal fishes like Sciaenidae because their close relationship with the bottom.

Transparency in bays is mainly associated with the resuspension of sediment by tidal movements and discharge of sediment from continental drainage. In the Sepetiba Bay, transparency presents a marked gradient with the lowest values in the inner zone, and the highest values in the outer zone. According to Cyrus \& Blaber (1992), areas with low transparency enhance protection against predators and indicate more food availability. Spatial segregation was evident for Sciaenidae populations in relation to transparency; C. gracilicirrhus, C. leiarchus and $M$. americanus occurred in higher transparent waters, while $M$. furnieri, in the lowest transparency. How the increasing transparency gradient from the inner to the outer zone is translated into species segregation in unknown, but the high correlation to fish abundance detected by the analyses indicates its important role as a factor influencing Sciaenidae distribution in the Sepetiba Bay.

According to Poxton \& Allouse (1982) the temperature can affect the distribution of the fish through the thermal tolerance that different species present. Although there is no available record on thermal differences among estuarine species, 
thermal limit may exist. WHEELER (1969) noticed that temperature affects the seasonality and variability of migration, spawning and recruitment patterns inside a given area. Thiel et al. (1995) recorded that temperature was the best predictor for fish abundance in the Elbe estuary, while salinity influenced species richness. In Sepetiba Bay, temperature was only a good predictor for C. leiarchus that was inversely correlated to this environmental variable. Since fish will not normally move outside their zone of temperature tolerance, higher temperature of the Sepetiba Bay, when compared to continental shelf can be a factor to dictate the distribution of C. leiarchus in the bay. Muto et al. (2000) found correspondence between cold South Atlantic Central Waters and the subtropical Sciaenidae community (Cynoscion guatucupa (Cuvier, 1829) and Umbrina canosai Berg, 1859), while tropical Sciaenidae (e.g. C. gracilicrrhus and Cynoscion jamaicensis) were more associated to warmer Coastal Water. This authores found that temperature and depth explain much of the distribution of the species.

The salinity has been mentioned as an environmental variable that influences the distribution of species (WAGNER \& Austin 1999, Whitfield 1999), although Attrill et al. (1999) have reported against the interpretation of the role of the salinity because of the multi-colinearity with other environmental variables. Weinstein et al. (1980) pointed to salinity as the most important environmental variable to influence fish distribution in estuaries; but in more stable environment such as the Sepetiba Bay, the influence of salinity may be less remarkable. Marshall \& Elliot (1998) reported that salinity in Humber estuary has a greater influence on the composition of the species than temperature. Similarly, in the present study, the salinity gradient along the zones of the bay was more important for species distribution than temperature, because three of the four studied species presented higher correlation with high salinity. Temperature and salinity did not show similar patterns of variation over the seasons and years, but changed consistently throughout the three bay zones.
AвоOKIRE et al. (2000) studying near shore fish distribution in relation to environmental gradients in Alaska found that oceanographic differences between areas accounted for most of the observed spatial differences in fish distribution, with higher abundance in the inner Bay compared with outer Bay; they stated that when physical and nutrient dynamics support high primary and secondary production, appropriatelyadapted fish species may be able to gain a trophic advantage, and this could be the case of M. furnieri in the inner Sepetiba bay. KuPSCHus \& TREMAIN (2001) studying associations between fish assemblages and environmental factors in a Florida coastal lagoon found spatial separation between the two most abundant Sciaenidae species, with Sciaenops ocellatus being more abundant in less saline and depth innermost areas, while Bairdiella chrysoura showed more widespread distribution, concentrating in seagrass cover patches; species common or cogeneric occurring in the Sepetiba bay (Menticirrhus americanos, Micropogonias undulatus and Cynoscon nebulosos) showed minor importance in this temperate coastal lagoon.

The functional value of bays as nurseries for fishes has been attributed to physiologically suitable physicochemical conditions, abundant prey resources and low predation risk (Power \& AtTrill 2002). It seems reasonable to suggest that the Sciaenidae family in the Sepetiba Bay evoluted in order to adapt different physicochemical conditions, mainly the two most closed related species $M$. furnieri and C. gracilicirrhus, which showed the more marked spatial segregation, avoiding competition by habitat partition. Both species are very similar in external morphology, like shape of the body, size and position of the mouth, and show similar generalist feeding behavior and trophic level, feeding mainly on crustacean and Polichaeta (Tab. IX). In aquatic communities, body shape and size and mouth position has been related directly to foraging success (KarPouzI $\&$ Stergiou 2003). These similarities could be the reason why they have adapted to explore different bay zones, with the abundant $M$. furnieri being more adapted to cope with harsh condi-

Table IX. Biological characteristics of the four most abundant Sciaenidae species in the Sepetiba Bay. References: (1) DelbeEK \& WilLiams (1988), (2) Stone \& Jessop (1994), (3) IsaAc (1988), (4) Naranjo (1956), (5) Mianzan et al. (1996), (6) Sierra et al. (1994), (7) Austin \& Austin (1971), (8) Vazzoler (1971), (9) Figueiredo \& Vieira (1998); (10) Chao (1978), (11) Cervigón (1993), (12) Cervigón et al. (1992), (13) Bowman et al. (2000).

\begin{tabular}{|c|c|c|c|c|}
\hline Species & Food behaviour & Biology & Diet & Feeding type \\
\hline M. furnieri & $\begin{array}{l}\text { Generalist opportunist } \\
\text { (Ref.1, 2) }\end{array}$ & $\begin{array}{l}\text { Sand-mud bottoms of } \\
\text { littoral zones preferably in } \\
\text { estuarine regions (Ref.3) }\end{array}$ & $\begin{array}{l}\text { Omnivorous (debris, zoobenthos, } \\
\text { zooplankton, crustaceans, } \\
\text { annelids, mollusks and fishes Ref. } \\
(4,5,6,7,8,9)\end{array}$ & $\begin{array}{l}\text { Mainly animals, trophic } \\
\text { level } 2.8 \text { to } 3.3 \text { (Ref.3, 6, 7) }\end{array}$ \\
\hline C. gracilicirrhus & $\begin{array}{l}\text { Generalist (Ref.10, 11), } \\
\text { Generalist seasonal fish }\end{array}$ & $\begin{array}{l}\text { Coastal waters occur in } \\
\text { sand-mud bottoms (Ref.10) }\end{array}$ & $\begin{array}{l}\text { Mainly benthic crustaceans and } \\
\text { polychaeta (Ref. } 10,11)\end{array}$ & $\begin{array}{l}\text { Mainly animals, trophic } \\
\text { level } 2.8 \text { up (Fishbase) }\end{array}$ \\
\hline M. americanus & $\begin{array}{l}\text { Hunting macrofauna } \\
\text { (predator) (Ref. 12) }\end{array}$ & $\begin{array}{l}\text { Inhabits coastal waters, } \\
\text { over sandy-mud to hard } \\
\text { sandy bottoms. }\end{array}$ & Main nekton (Ref. 13) & $\begin{array}{l}\text { Mainly animals, trophic } \\
\text { level } 2.8 \text { up (3.9) } \\
\text { (Fishbase) }\end{array}$ \\
\hline C. leiarchus & $\begin{array}{l}\text { Hunting macrofauna + } \\
\text { fish (predator) }\end{array}$ & $\begin{array}{l}\text { Found over mud and sand } \\
\text { bottoms in river estuaries }\end{array}$ & Fish and crustaceans & $\begin{array}{l}\text { Mainly animals, trophic } \\
\text { level } 2.8 \text { up }\end{array}$ \\
\hline
\end{tabular}


tions in more rich inner bays area, while C. gracilicirrhus explore a more stable environmental condition near to the sea limit. The other two abundant species seems to respond in a different way to environmental constraints. Furthermore, the increasing degradation process that the bay is undergoing in the last decade could alter species distribution. In the inner zone, organic nutrients from urban areas enrich the water where fewer fish species may tolerate compared to higher water quality in the outer zone (PFeiffer et al. 1985).

Each one of the four most abundant Sciaenidae species may have evoluted to explore different habitat, avoiding competition by spatial segregation along their distribution area, or by colonization and occupation of empty patches. Some theories can explain such patterns, among them, feeding strategies and predation avoidance. In the Sepetiba Bay the dominant $M$. furnieri could be forcing the sub-dominant M. americanus distribution out of the inner bay zone, a species less adapted to copy with harsher environmental conditions, maintaining the local coexistence. Armstrong \& Macgenee (1976) predicts coexistence unless the environmental changes by a magnitude that exceeds the dispersal ability of the local sub-dominant species relative to that of its dominant competitor. It is also possible that $M$. americanus could copy with the inner zone conditions, but it would be not able to compete against the more adaptable $M$. furnieri, keeping its distribution in the middle and outer zones. Additionally, lower densities of other Sciaenidae populations could be capable of reaching the inner bay zone but not in sufficient numbers to avoid the dangers of small population size or even arriving in force but are unable to survive in harsher physico-chemical condition that M. furnieri affords.

Overall, the members of the Sciaenidae family in the Sepetiba Bay did not differ from others in bays and estuaries at Southeastern and Southern Brazil. This group shows high richness, and was comprised by nine species in Sepetiba Bay $\left(23^{\circ} \mathrm{S}\right)$, being dominated by $M$. furnieri. This species is also the dominant Sciaenidae in Guanabara Bay $\left(23^{\circ}\right.$ S) (AвREu-Lima personal communication), a very closed embayment in Rio de Janeiro State, and in Patos Lagoon estuary, a $2000 \mathrm{~km}$ far away area in Southern Brazil $\left(33^{\circ} \mathrm{S}\right)$ (Pereira 1994), with both areas presenting 10 Sciaenidae species. In the Santos Bay $\left(24^{\circ} \mathrm{S}\right)$, Giannins \& Paiva-Filho (1990) reported 20 species of Sciaenidae, including those from continental shelf, and only six out from the 20 species, comprised about $90 \%$ of the total number of fish, ranking in the following decreasing order: Stellifer rastrifer, Isopisthus parvipinnis, Paralonchurus brasiliensis, M. furnieri, Stellifer brasiliensis and M. americanus. ARAújo et al. (1998), studying fish assemblages in the Sepetiba Bay, reported that M. furnieri ranked in fourth place in the number of fish species, while $C$. leiarchus ranked at $11^{\circ}$ place, contributing together to $43,7 \%$ of the total number of fish caught in 1993/1994. In the Patos Lagoon estuary, PEREIRA (1994) reported that the Sciaenidae family shares the numerical abundance with the Ariidae family, with the Sciaenidae contributing to $61,4 \%$ of the total number of fish, and $M$. furnieri comprising alone $36,8 \%$ of the number, followed by $M$. americanus $(18,8 \%)$ and P. brasiliensis $(2,9 \%)$. Although it is difficult to compare species richness and relative abundance in different areas, which present different habitat heterogeneity and that were searched with different fishing effort, it was evidenced that these bays and estuarine areas play an important role in life cycle for this group of fishes. Reasons to explain shifts in top abundant species seem to be more associated to microhabitat diversity in each area than latitudinal variation along the Southeastern and Southern Brazilian coast.

In conclusion it is postulated that environmental constraints in Sepetiba Bay is structuring the densities of the top abundant Sciaenidae species and spatial segregation is the outcome for species-specific response to environmental gradient. Species interactions and competition in the present or in the past could also play a role in this distribution pattern resulting in habitat partition.

\section{ACKNOWLEDGEMENTS}

We thank Pablo Mendonça, Roberto Guião de Souza Lima, Márcia Cristina Costa de Azevedo, André Luiz Machado Pessanha, and Márcio de Araújo Silva for helping with fieldwork. The work is a portion of the first author's MSc dissertation for the Animal Biology Course, Universidade Federal Rural do Rio de Janeiro. The Rio de Janeiro Research Agency (FAPERJ) and Brazilian Agency for Research Development (CNPq) provided financial support.

\section{REFERENCES}

Abookire, A.A.; J.F. PiatT \& M.D. Robards. 2000. Nearshore fish distributions in an Alaskan Estuary in relation to stratification, temperature and salinity. Estuarine, Coastal and Shelf Science, Stirling, 51: 45-59.

Araújo, F.G.; A.G. Cruz-Filho; M.C.C. Azevedo \& A.C.A. SanTos.1998. Estrutura da comunidade de peixes demersais da Baía de Sepetiba, RJ. Revista Brasileira de Biologia, São Carlos, 58: 417-430.

Araújo, F.G.; M.C.C. Azevedo; A.L.M. Pessanha; M.A. Silva \& I.D. GOMEs. 2002. Environmental influences on the demersal fish assemblages in the Sepetiba Bay, Brazil. Estuaries, Kansas, 25: 441-450.

Armstrong, R.A. \& R. Macgehee.1976. Coexistence of species competing for shared resources. Theoretical and Population Biology, Stanford, 9: 317-28.

AtTrill, M.J.; M. POWER \& R.M. Thomas. 1999. Modelling estuarine Crustacean population fluctuations in response to physicochemical trends. Marine Ecology Progress Series, Oldendorf, 178: 89-99.

Austin, H. \& S. Austin. 1971. The feeding habits of some juvenile marine fishes from the mangroves in western Puerto Rico. Caribbean Journal of Science, Mayaguez, 10 (3/4): 171178. 
Barbiére, E.B. \& D.M.P. Kronemberger. 1994. Climatologia do Litoral Sul-Sudeste do estado do Rio de Janeiro. Caderno de Geociências do Rio de Janeiro, Rio de Janeiro, 12: 57-73.

Blaber, S.J.M. \& T.G. Blaber.1980. Factors affecting the distribution of juvenile estuarine and inshore fish. Journal of Fish Biology, Dumfries, 17: 143-162.

Bowman, R.E.; C.E. Stillwell; W.L. Michaels \& M.D. Grosslein. 2000. Food of northwest Atlantic fishes and two common species of squid. Seattle, NOAA Technical Memo NMFSNE, \#155, 138p.

Castello, J.P. 1986. Distribuicíon, crescimiento e maduracion sexual da la corvina juvenil (Micropogonias furnieri) en el estuario de la Lagoa dos Patos, Brasil. Physis, Buenos Aires, 44: 21-36.

Cervigón, F. 1993. Los peces marinos de Venezuela. Caracas, Fundación Científica Los Roques, vol. 2, 497p.

Cervigón, F.; R. Cipriani; W. Fischer; L. Garibaldi; M. Hendrickx; A.J. Lemus; R. Márquez; J.M. Poutiers; G. Robaina \& B. Rodriguez. 1992. Fichas FAO de identificación de especies para los fines de la pesca. Guía de campo de las especies comerciales marinas y de aquas salobres de la costa septentrional de Sur América. Rome, FAO, 513p.

CHAO, L.N. 1978. Sciaenidae. In: W. FIscher (Ed.). FAO species identification sheets for fishery purposes. West Atlantic (Fishing Area 31). Rome, FAO, vol. 4.

Coelho, V.M.B. \& R.R. Carvalho. 1973. Levantamento sanitário da Baía de Sepetiba e suas possibilidades como corpo receptor de cargas poluidoras da região. Rio de Janeiro, Publicações Avulsas FEEMA, 87p.

Cyrus, D.P. \& S.J.M. Blaber. 1992. Turbidity and salinity in a tropical Northern Australian estuary and their influence on fish distribution. Estuarine, Coastal and Shelf Science, Stirling, 35: 543-545.

Delbeek, J.C. \& D.D. Williams. 1988. Feeding selectivity of four species of sympatric stickleback from the east coast of Canada. Journal of Fish Biology, Dumfries, 32: 41-62.

DruZHinIN, A.D. 1974. On the distribution and biology of drums (or croakers)-Sciaenidae family-throughout the world ocean. Ichthyologia, Sarajevo, 6: 37-47.

FARGO, J. \& A.V. TYLER. 1991. Sustainability of flatfish-dominated fish assemblages in Hecate Strait, British Columbia, Canada. Netherland Journal of Sea Research, Denburg, 27: 237253.

Figueiredo, G.M. \& J.P. Vieira. 1998. Cronologia e dieta alimentar da corvina, Micropogonias furnieri, no estuário da Lagoa dos Patos, RS, Brasil. Atlântica, Rio Grande, 20: 55-72.

FiperJ. 1998. A pesca no Estado do Rio de Janeiro em 1998. Análise das estatísticas de desembarque. Rio de Janeiro, Fundação Instituto de Pesca do Estado do Rio de Janeiro, 20p.

Fisher, W. \& G. BIANCHI. 1984. FAO species identification sheets for fishery purposes - Western Indian Ocean. Rome, FAO, vol. 4.
Fonseca, M.R.M.B. 1978. Qualidade da água da Baía de Sepetiba. FEEMA, Meio Ambiente, Rio de Janeiro, 2: 316-334.

Giannini, R. \& A.M. Paiva Filho. 1990. Os Sciaenidae (Teleostei: Perciformes) da Baía de Santos (SP), Brasil. Boletim do Instituto Oceanográfico, São Paulo, 14: 3-12.

Haimovici, M.; S.D. Pereira \& P.C. Vieira. 1989. La pesca demersal en el sur de Brasil en el periodo 1975-1985. Frente Marítimo, Montevidéo, 5: 151-163.

Harris, S.A..; D.P. Cyrus \& L.E. Beeckley. 2001. Horizontal trends in larval fish diversity and abundance along an oceanestuarine gradient on the Northern KwaZulu-Natal coast, South Africa. Estuarine Coastal and Shelf Science, Stirling, 53: 221-235.

IsAAC, V.J. 1988. Synopsis of biological data on the whitemouth croacker Micropogonias furnieri (Desmarest, 1823). Rome, FAO Fisheries Synopsis 150, 35p.

Karpouzi, V.S. \& K.I. Stergiou. 2003. The relationships between mouth size and shape and body length for 18 species of marine fishes and their trophic implications. Journal of Fish Biology, Dumfries, 62: 1353-1365.

Kupschus, S. \& D. Tremain. 2001. Associations between fish assemblages and environmental factors in nearshore habitats of a subtropical estuary. Journal of fish Biology, Dumfries, 58: $1383-1403$.

Lima-Junior, R.G.S.; F.G. Araújo; M.F. Maia e Pinto \& A.S.S.B. Pinto. 2002. Evaluation of Heavy Metals in Fish of the Sepetiba and Ilha Grande Bays, Rio de Janeiro, Brazil. Environmental Research, Baltimore, 89 (Section A): 171-179.

Livingston, R.J. 1976. Diurnal and seasonal fluctuations of organisms in a North Florida estuary. Estuarine Coastal Marine Science, Stirling, 4: 373-400.

Longhurst, A.R. \& D. PAuly. 1987. Ecology of tropical oceans. San Diego, Academic Press, 407p.

Marshall, S. \& M. Elliott. 1998. Environmental influences on the fish assemblage of the Humber estuary, U.K. Estuarine Coastal and Shelf Science, Stirling, 46: 175-184.

Mianzan, H.W.; N. Mari; B. Prenski \& F. Sanchez. 1996. Fish predation on neritic ctenophores from the Argentine continental shelf: a neglected food resource? Fisheries Research, Amsterdam, 27: 69-79.

Muto, E.Y.; L.S.H. SoARes \& C.L.D.B. Rossi-WongtschowsKi. 2000. Demersal fish assemblages of São Sebastião, southeastern Brazil: structure and environmental conditioning factors (summer 1994). Revista Brasileira de Oceanografia, São Paulo, 48 (1): 9-2.

NARANJO, A. 1956. Cordel y anzuelo. La Habana, Editorial Cenit, 251p.

Pereira, L.E. 1994. Variação diurnal e sazonal dos peixes demersais na barra do estuário da Lagoa dos Patos, RJ. Atlântica, Rio Grande, 16: 5-21.

Pessanha, A.L.M.; F.G. Araújo; M.C.C. Azevedo \& I.D. Gomes. 2000. Variações temporais e espaciais na composição e estrutura da comunidade de peixes jovens da Baía de Sepetiba, Rio de

Revista Brasileira de Zoologia 23 (2): 497-508, junho 2006 
Janeiro. Revista Brasileira de Zoologia, Curitiba, 17: 251261.

Pfeiffer, W.C.; L.D. Lacerda; M. Fiszman \& N.R.W. Lima. 1985. Haevy metal in fishes from Sepetiba Bay, Rio de Janeiro State. Ciência e Cultura, Rio de Janeiro, 37: 297-302.

Power, M. \& M.J. AtTrill. 2002. Factors affecting long-term trends in the estuarine abundance of Pogge (Agonus cataphractus). Estuarine Coastal and Shelf Science, Stirling, 54: 941-949.

PoxTon, M.G. \& S.B.AlLousE. 1982. Water quality criteria for marine fisheries. Aquacultural Engeniering, Seattle, 1: 153-191.

Rosenzweig, M.L. 1981. A theory of habitat selection. Ecology, Washington, 62: 327-335.

Rosenzweig, M.L. 1991. Habitat selection and populations interactions: the search for mechanism. American Naturalist, Chicago, 137: S5-S28.

SASAKI, K. 1996. Sciaenid fishes of the Indian Ocean (Teleostei, Perciformes). Memories Faculty Science Kochi University Series D: Biology, Kochi, 16/17: 83-95.

Sierra, L.M.; R. Claro \& O.A. Popova. 1994. Alimentacion y relaciones tróficas, p. 263-284. In: R. Claro (Ed.). Ecología de los Peces Marinos de Cuba. Quintana Roo, Instituto de Oceanología Academia de Ciencias de Cuba, Centro de Investigaciones de Quintana Roo, 525p.

STONE, H.H. \& B.M. Jessop. 1994. Feeding habits of anadromous alewifes, Alosa pseudoharengus, off the Atlantic Coast of Nova Scotia. Fishery Bulletin, La Jolla, 92: 157-170.

Storch, D. \& D. Frynta. 1999. Evolution of habitat selection: stochastic acquisition of cognitive clues? Evolutionary Ecology, Nijmegen, 13: 591-600.

Ter Braak, C.J.F. 1991. Update notes: Canoco Version 3.1. Wageningen, Agricultural Mathematics Group, 35p.
Ter BraAk, C.J.F. \& P.F.M. Verdondchot. 1995. Canonical correspondence analysis and related multivariate methods in aquatic ecology. Aquatic Sciences, Dubendorf, 57: 255-289.

Thiel, R.; A. Sepulveda; R. Kafemann \& W. Nellen. 1995. Environmental factors as forces structuring the fish community of the Elbe estuary. Journal of fish Biology, Dumfries, 46: 4769.

Trewavas, E. 1977. The sciaenid fishes (croakers or drums) of the Indo-west-Pacific. Transaction Zoology Society of London, London, 33: 259-541.

VAZzolER, A.E.A. DE M. 1971. Diversificação fisiológica e morfológica de Micropogon furnieri (Desmarest, 1823) ao sul de Cabo Frio, Brasil. Boletin do Instituto Oceanográfico, São Paulo, 20 (2): 1-70.

Wagner, C.M. \& H.M. Austin. 1999. Correspondence between environmental gradients and summer littoral fish assemblages in low salinity reaches of the Chesapeake Bay, USA. Marine Biology Progress Series, Oldendorf, 177: 197-212.

Weinstein, M.P.; S.L.Weiss \& M.F. WaLters. 1980. Multiple determinants of community structure in shallow marsh habitats, Cape Fear River estuary, North Carolina. Marine Biology, Oldendorf, 58: 227-243.

Wheeler, A. 1969. Fish-life and pollution in the lower Thames: a review and preliminary report. Conservation Biology, Gainesville, 2: 25-30.

Whitfield, A.K. 1999. Ichthyofaunal assemblages in estuaries: a South African case study. Fish Biology and Fisheries, Anchorage, 9: 151-186.

WhitTaker, R.H. \& S.A. Levin. 1975. Niche: theory and application. Benchmark Papers in Ecology, Stroudsburg, 3: 1-448.

ZAR, J.H. 1984. Biostatistical Analysis. New Jersey, Prentice Hall, $718 \mathrm{p}$.

Received in 24.VI.2005; accepted in 11.V.2006. 